\title{
An Empirical Study of Corporate Brand Image, Customer Perceived Value and Satisfaction on Loyalty in Shoe Industry
}

\author{
*Yu-Te Tu${ }^{1}$, Mei-Lien $\mathrm{Li}^{2}$, Heng-Chi Chih ${ }^{3}$ \\ ${ }^{1}$ Chungyu Institute of Technology Keelung, Taiwan \\ ${ }^{2}$ Fortune Institute of Technology, Taiwan \\ ${ }^{3}$ General Education Center, Wenzao Ursuline College of Languages, Taiwan \\ *suntu@ms18.hinet.net
}

\begin{abstract}
A positive corporate brand image is not only increasing competition but also encourage consumers to repurchase. With loyal customers, companies can reduce the operating cost and acquisition expenses. This initial study was from relevant literature, then set up research structure and hypotheses. Survey was employed, and respondents collected from the customers of ASO in Taiwan. There were 208 usable questionnaires to analyze descriptive statistics, reliability, validity, and SEM model. Based on the research results, corporate brand image significantly affects customer perceived value, customer satisfaction and loyalty; customer perceived value has strong impact on customer satisfaction and loyalty for the sample; and customer satisfaction significantly affects customer loyalty. Therefore, companies should have a positive brand image to customers, and specifically focus on those factors in order to build a long-term and mutually profitability relationships with customers and create loyalty as competitive advantages in the markets. The study focuses on the industry of shoes in Taiwan, and adopts only a quantitative method. Future research could employ a different design to examine the causal relationships posited by the theories, and extension the study to discuss mediation or moderation among dimensions.
\end{abstract}

Keywords: Corporate brand image, perceived value, satisfaction, loyalty, SEM

\section{Introduction}

ASO, found in 1952, is one of the most popular retail elephants of shoes in Taiwan. In the earlier age, ASO, in the minds of the older generation of consumers, represent a name of durable and comfortable shoes. As long as ever being ASO customers, the repurchasing rate is high, and ASO builds quite successful relationships on customer loyalty. However, for younger people, the name of the ASO sound is a local brand, and in this area of development the young consumer groups is blank. ASO set out to change the CIS corporate image in 2003, and ASO is as a new brand. They focus on value-added brand in order to obtain the majority competitive strength in the shoe marketing in Taiwan. Presently, ASO has 250 distribution 
channels, and annual revenue increased from US\$ 40 million in 2003 to US\$120 million in 2011 (ASO, 2013). Park, Jaworski and Maclnnis (1986) reported that brand could be a symbol or sign to identify the product for customers and have better competitive advantage and increased market share. Davies, Chun, Da Silva and Roper (2003) indicated that anything can be a brand, such as a company, corporate or name. Roth (1994) indicated that brand image was customer reactions mixed with marketing programs by the manufacturer. Ind (1997) reported that when consumers purchase products from a company, they not only buy products but also receive a set of values form the company. Corporate brands are a sum of values representing the corporate (Ind, 1997), and a positive corporate brand image is not only help companies to increase competition but also encourage consumers to re-purchases (Porter \& Claycomb, 1997). Moliner, Sanchez, Rodriguez and Callarisa (2007) defined customer perceived value is the perceived worth in functional value of goods or service quality and price, emotional value of feeling, and social value of social impact from self-experiences and other alternatives.

Webster (1994) reported that customers have become the most important strategic resources. Berry and Parasuraman (1991) indicated that it will be higher cost of five to seven times for attracting a new customer than keep an existing one. Oliver and Swan (1989) also posited that most dissatisfied customers did not complain. Many researchers pointed out that with loyal customers, companies can increase revenue. Loyal customers are less price sensitive, and the premiums of loyal customers increase 8 percent annually in the personal insurance industry (Reichheld \& Teal, 1996). Loyal customers are willing to purchase frequently, try the firms' other products or services, and bring new customers to the firms (Reichheld \& Sasser, 1990). It is important ways of maximizing retention and minimizing defections of customer for companies to increase market share (Verhoef, 2003). Reichheld and Teal (1996) further indicate that customer loyalty provides a foundation for a firm to examine their marketing strategy, relationship quality improvement activities, and value creation program. Customer satisfaction has shown as an important factor to impact tendencies of attitude and behavior toward chosen brands (Lei \& Jolibert, 2012). Morgan (2000) reported that it can increase the customer satisfaction of usage with the good brand image, and recommend to other people. Romaniuk and Sharp (2003) also found that both brand image and customer satisfaction have positive relationship. Customer satisfaction is an important driver to customer loyalty and the success of businesses (Oliver, 1997). Studies have found positive evidence on the direct relationship between customer satisfaction and loyalty of repeat purchase, less price sensitive, cross-buying behavior, and profit (Bloemer \& Odekerken-Schroder, 2002; Ibrahim \& Najjar, 2008; Oliver, 1997). However, several studies (Dimitriades, 2006; Jones, 1996; Woodruff, 1997) show that satisfied customers do defect. For example, when customers say they are satisfied, they still purchase elsewhere (Jones, 1996). Marketing exists to deliver more value to satisfy customers as well as build a long-term and mutually profitability relationship with customer (Kotler, 2005). Thus, the purpose of this study is to explore the influences of corporate brand image, customer perceived value and customer satisfaction on customer loyalty for retail stores of shoes. 


\section{Literature Review}

Corporate brand image: Magid, Anthony and Dena (2006) reported that brand image was customer responses to brand name, sign, or impression, and represented the product quality, too. Brand image was a set of assets and liabilities, and it linked with brand name and sign that the assets and liabilities could increase or reduce the value by providing products or services to customers (Magid, Anthony \& Dena, 2006). Porter and Claycomb (1997) reported that brand image could be measured from two dimensions including the symbol and function, and the items focused on the utility of the brand regarding the function, and contained symbolic image. Keller (1993) defined brand image is a perception about a brand held in consumer memory. Corporate brands are intangible assets for companies that are difficult to imitate, and it is different from products brands as emphasizing the important of brand values (De-Chernatony, 1999). Consumers more favorable the image has higher perceived in quality, value, satisfaction and loyalty (Johnson, Andreessen, Lervik \& Cha, 2001). Aaker (1996) measured brand image through three dimensions, such as (1) brand value, (2) brand characteristics, and (3) brand associations. $\mathrm{Wu}$ (2011) reported that corporate image is an important antecedent of customer satisfaction and loyalty. Selnes (1993) also confirmed that corporate brand image has the influence on brand loyalty. In contrast, Davies and Chun (2002) found that corporate brand image had an indirect influence on brand loyalty.

Customer perceived value: Zeithaml (1988) indicated that customer perceived value is as "the customer's overall assessment of the utility of a product based on perceptions of what is received and what is given" (p. 14). Customer perceived value (CPV) is identified by terms of value (Monroe, 1990; Zeithaml, 1988) or customer value (Butz \& Goodstein, 1996). Holbrook (1994) mentioned that customer value is "the fundamental basis for all marketing activity" (p. 22). Sirdeshmukh, Singh and Sabol (2002) reported that customer value is a super-ordinate goal as it is a behavioral intention. Sirdeshmukh et al., 2002, also indicated that customer value regulates "behavioral intentions of loyalty toward the service provider as long as such relational exchanges provide superior value" (p. 21). Chang and Wildt (1994) posited that customer perceived value is a major contributor to purchase intention. Delivering value to customers is to develop loyal customers who can increase purchase frequency, purchase quantity, and avoid of switching behavior (Rust, Lemon \& Zeithaml, 2004). Therefore, transferring customer value is the manner to building a firm's competitive advantage (Lee \& Overby, 2004; Ulaga \& Chacour, 2001; Woodruff, 1997). Petrick (2002) posited that perceived value of service comprises five dimensions including quality, emotional response, monetary price, behavioral price, and reputation. Zeithaml (1988) defined that CPV is the consumer's overall evaluation of a product based on perceptions of what is received and what is given. Woodruff (1997) defined customer perceived value is a process from pre-purchase, transaction, and post purchase aspect in use situations. Zeithaml (1988) mentioned that customer perceived value is a key elementary to decide customer loyalty; affects consumer purchasing 
intention (Cronin, Brady, Brand, Hightower \& Shemwell, 1997); and has a positive effect on customer satisfaction (Patterson and Spreng, 1997).

Customer satisfaction: Joewono and Kubota (2007) indicated that customer satisfaction was from the product and service evaluations according to the customer experiences as well as the overall measurement on the consuming experience. According to Oliver (1997), satisfaction is defined from the mixture of both affection (emotion) and cognition approach as "the consumer's fulfillment response. Zeithaml and Bitner (2000) indicated that customer satisfaction was multidimensional measurements including service quality, product quality, scenario factor, personal factor, and price factor. Satisfaction can be separated into two approaches either as a transaction-specific satisfaction (Olsen \& Johnson, 2003) or as a cumulative satisfaction/ post-consumption satisfaction (Oliver, 1997). After 1990s, many researchers view satisfaction as customers' cumulative, after purchase, and overall judgment about purchasing behavior (Johnson, Anderson, \& Fornell, 1995; Engel \& Blackwell, 1982; Hunt, 1977; Tse \& Wilton, 1988). Ostrom and Iacobucci (1995) announced that five dimensions can measure customer satisfaction, such as (1) price of goods, (2) service efficiency, (3) attendant attitude, (4) overall performance of the company, and (5) the closeness to the ideal company.

Customer satisfaction is viewed as influencing repurchase intentions and behavior, which, in turn, leads to an organization's future revenue and profits. DeMatos and Rossi (2008) reported that satisfied customers will provide positive word-of-mouth communications to others. In contrast, Bowen and Shoemaker (2003) indicated that satisfied customers may not spread positive word-of-mouth communications, because companied may does not deliver what customers need or want (Roig, Garcia, Tena \& Monzonis, 2006). Customer satisfaction is an important driver to customer loyalty and the success of businesses (Oliver, 1997). Studies have found positive evidence on the direct relationship between customer satisfaction and loyalty of repeat purchase, less price sensitive, cross-buying behavior, and profit (Bloemer \& Odekerken-Schroder, 2002; Ibrahim \& Najjar, 2008; Oliver, 1997). However, several studies (Dimitriades, 2006; Jones, 1996; Woodruff, 1997) show that satisfied customers do defect. For example, when customers say they are satisfied, they still purchase elsewhere (Jones, 1996).

Customer loyalty: Oliver (1997) defined customer loyalty is as "a deeply held commitment to re-buy or re-patronize a preferred product or service consistently in the future, despite situational influences and marketing efforts having the potential to cause switching behavior" (p. 392). Customer loyalty can be classified as brand loyalty, service loyalty, and store loyalty (Dick \& Basu, 1994). Customer loyalty is a strategy that creates mutual rewards to benefit firms and customers (Reichheld \& Detrick, 2003). With loyal customers, companies can maximize their profit because loyal customers are willing to (1) purchase more frequently; (2) spend money on trying new products or services; (3) recommend products and services to others; and (4) give companies sincere suggestions (Reichheld \& Sasser, 1990). Between the 
frequency of loyalty and repurchase has been complicated by the buyer switching behavior due to the individual level and the market level (Breivik \& Thorbjornsen, 2008). Jones and Sasser (1995) indicated that customer intention could be measured by their future intentions to repurchase product or service again, and customer repurchase intention can be measured by making relationship with customer, and it is a significant indicator of future behavior. Thus, loyalty links the success and profitability of a firm (Eakuru \& Mat, 2008). Customer loyalty is commonly distinguished in three approaches including behavioral loyalty approach (Grahn, 1969); attitudinal loyalty approach (Bennett \& Rundle-Thiele, 2002; Jacoby, 1971; Jacoby \& Chestnut, 1978), and integration of attitudinal and behavioral loyalty approach (Dick \& Basu, 1994; Jacoby, 1971; Jacoby \& Chestnut, 1978; Oliver, 1997). Oliver (1997) reported that there are four stages for customers to be a loyal customer: (1) a cognitive sense (belief); (2) the affective sense (favored attitude); (3) conative stage that consumers have a behavioral intention; and (4) action. Therefore, viewing loyalty as an attitude-behavior relationship allows integrated investigation of antecedents and consequences of customer loyalty (Dick \& Basu, 1994).

The theoretical propositions inform the development of following hypothesized model and research hypotheses.

Figure 1: Hypothesized Model

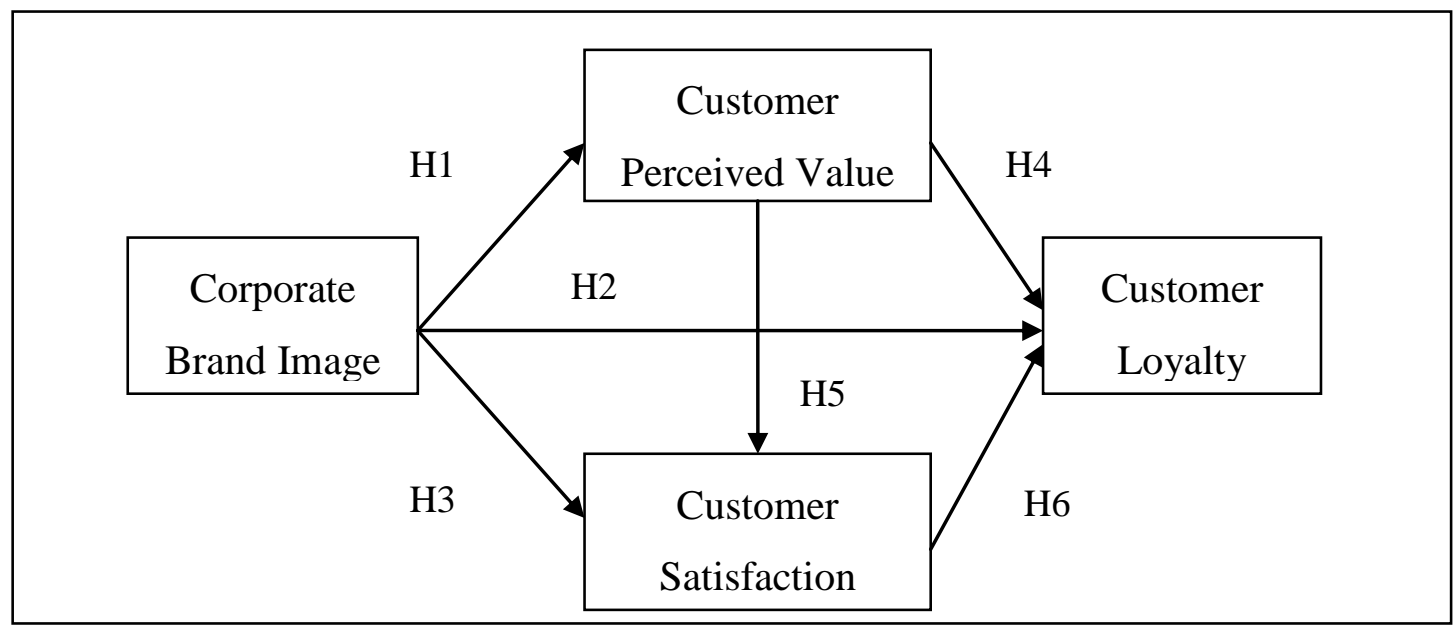

\section{Research hypotheses:}

H1: The corporate brand image is a direct path, and significantly affects the customer perceived value.

$\mathrm{H} 2$ : The corporate brand image is a direct path, and significantly affects the customer loyalty.

H3: The corporate brand image is a direct path, and significantly affects the customer satisfaction.

H4: The customer perceived value is a direct path, and significantly affects the customer loyalty.

H5: The customer perceived value is a direct path, and significantly affects the customer satisfaction.

H6: The customer satisfaction is a direct path, and significantly affects the customer loyalty. 


\section{Methodology}

A quantitative, non-experimental, and explanatory (correlational) study was conducted to assess the relationships among corporate brand image, customer perceived value and customer satisfaction on customer loyalty.

Instrumentation: A five-part questionnaire for the study was developed by the researchers in order to measure the research variables. In the questionnaire, five of the items were designed to examine corporate brand image according to the theory of Ind in 1997 and De Chertanony in 2000; five of the items were developed to test customer perceived value according to the theory of Moliner, Sanchez, Rodriguez and Callarisa in 2007; five of the items were designed to examine customer satisfaction according to the theory of Oliver in 1997; and five of the items were developed to test customer loyalty according to the theory of Reichheld and Sasser in 1990. All variables are by means of a five-point Likert scale, and ranged from strongly agree (5) to strongly disagree (1). These socio-demographic questions and the coding schemes used included: Gender: $1=$ male; $2=$ female. Age: $1=$ under $25 ; 2=25-35 ; 3=$ 36-45; and $4=$ over 46 . Frequency of purchase: $1=1$ time/year or below; $2=2$ times/year; $3=3$ times/year; and $4=4$ times/year or over.

Population: In this study, the survey was distributed to customers in a public area through face-to-face invitation outside the main entrance of ASO in Taipei city and New Taipei city, which is a famous store and focuses on products of shoes during the weekday and weekend. The systematic random sampling plan was employed to select participants. Every fifth customer was invited. If the fifth customer is not willing to participate, the next eligible customer was selected. When customers agreed to participate, participants were given a survey questionnaire on a clipboard, and retrieved the questionnaire after finished.

Methods of data analysis: Hair, Black, Babin, and Anderson (2010) indicated that structural equation modeling (SEM) has become a popular multivariate approach because it provides a means of assessing theories that is conceptually appealing. AMOS software (version 18.0), which includes an SEM package with maximum likelihood estimation, was used to test both the measurement and the structural models that related to the research hypotheses listed. The present research also made use of a number of criteria to determine the inclusion of items and the goodness of fit of the model. Hair et al. (2010) suggested a six-stage procedure for employing SEM, which the research also followed here. 


\section{Results}

There were 217 questionnaires returned, but 9 questionnaires were incomplete or consistent answers. All questionnaires were coded for statistical analysis using the SPSS 14.0. From the 208 respondents, in total, 77 (37.0\%) respondents were male and 131 (63.0\%) were female. 13 (6.3\%) of the respondents were under 25 years old, 57 (27.4\%) were between 25 and 35, 78 (37.5\%) were between 36 and 45 and $60(28.8 \%)$ were older than 45 . In the study, 175 (84.1\%) respondents had frequency of purchase one time per year or under, $30(14.4 \%)$ had frequency of purchase two times per year, 2 (1.0\%) had frequency of purchase three times per year, and $1(.5 \%)$ had frequency of purchase four times per year or over.

The univariate normality of the skewness and kurtosis values and the multivariate normality were used to assess the normality. The most commonly used critical values of univariate normality are \pm 3 and \pm 10 (Kline, 1998). In the study, all the values of skewness were between -.54 and .05, and the values of peakedness lay between -.62 and .80 . The observed variables all had univariate normal distributions. The value of Mardia statistic is for multinormality measurement, and it is constructed a test based on skewness and kurtosis. Bollen (1989) indicated that if the value of Mardia is smaller than $p(p+2), p$ indicating the amount of observed variables, all dimensions are multinormality. In the study, the value of Mardia is 12.07 , smaller than $20(20+2)$, indicating multivariate normality distribution. The validity of the construct was measured using the convergent and discriminant validity. The convergent validity was used to determine whether scale items converged on a single construct during measurement (Steenkamp \& Van Trijp, 1991). This was determined from the evaluation of the factor loadings (which must be at least 0.5 ), composite reliability (at least 0.6 ) and average extracted variance (at least 0.5 ) in the study (Hair et al. 2010; Fornell \& Larcker, 1981). In the structural models, all the factor-loading estimates were higher than .50 , all the composite reliability $(\mathrm{CR})$ values ranged from .78 to .87 , and all the extracted average values of variance lay between .41 and .57, as shown in Tables 1.

Table 1: Standardized parameter estimates, composite reliability and average variance extracted values for the structural model

\begin{tabular}{|c|c|c|c|c|}
\hline Construct & Indicator & Standardized Parameter Estimates & AVE & CR \\
\hline \multirow{5}{*}{$\begin{array}{l}\text { Corporate } \\
\text { Brand Image }\end{array}$} & CBI 1 & .58 & \multirow{5}{*}{.44} & \multirow{5}{*}{.80} \\
\hline & CBI 2 & .67 & & \\
\hline & CBI 3 & .76 & & \\
\hline & CBI 4 & .78 & & \\
\hline & CBI 5 & .50 & & \\
\hline Customer & PV 1 & .56 & \multirow{2}{*}{.41} & \multirow{2}{*}{.78} \\
\hline Perceived Value & PV 2 & .58 & & \\
\hline
\end{tabular}




\begin{tabular}{llllll} 
& PV 3 & .71 & .70 & & \\
& PV 4 & .65 & .57 & .87 \\
Customer & PV 5 & .69 & & \\
Satisfaction & CS 1 & .75 & & \\
& CS 2 & .79 & .80 & & \\
& CS 4 & .74 & & \\
Customer & CS 5 & .50 & .42 & \\
Loyalty & CL 1 & .58 & & \\
& CL 2 & .70 & & \\
& CL 3 & .75 & & \\
\hline
\end{tabular}

Bagozzi and Phillips (1982) stated that metrics support discriminant validity if the upper and lower limits of the computed confidence interval did not include the number 1 . In the present research, a model was constructed for each of the 6 paired correlations of the latent variables. Then, the correlation was set between the two constructs to 1 , and a 95 percent confidence interval was applied in order to apply a bootstrap. As the results, all values of paired correlations of the latent variables were from .21 to .84, the number 1 is not included with the upper and lower limits of the confidence interval, which indicates discriminant validity among the theoretical constructs. The results of the SEM model shown in Figure 2 were obtained using AMOS 18.0, and the model fits are reported in Table 2. The overall model fit $\chi^{2}$ was 259.35 with 164 degrees of freedom. The p-value associated with this result was .000. The value of RMSEA, an absolute fit index, was .05. This value is smaller than the guideline value of .08 for a model with 20 measured variables and a sample size of 208. Therefore, RMSEA supports the model fit. The value of GFI (.89) was slight lower than the guideline value. RMR had a value .04. SRMR (.045) was smaller than .05 . The normed $\chi^{2}$ was 1.58 . This measure is the chi-square value divided by the number of degrees of freedom. A number smaller than 3.0 is considered to be very good. Thus, the normed $\chi^{2}$ suggests an acceptable fit for the structural model.

In the SEM model, the CFI had a value of .94, which exceeds the CFI guidelines for a model of this complexity and sample size. The other incremental fit indices (NFI = .85) is slight lower than the suggested cutoff values. All the incremental fit indices presented an acceptable fit. The parsimony index of AGFI had a value of .86 and the PNFI was .73. Both indices were considered to represent a good model fit, given the acceptable critical value. The overall structural fit results of these analyses showed that the model provides a reasonable fit. 
Table 2: Comparisons of goodness-of-fit indices of SEM models

\begin{tabular}{|c|c|c|}
\hline GOT Indices & Criterion Guidelines & SEM Results \\
\hline \multicolumn{3}{|l|}{ Chi-square $\left(\chi^{2}\right)$} \\
\hline Chi-square & & 259.35 \\
\hline Degree of freedom & & 164 \\
\hline Probability & p>.05 (Jöreskog \& Sörbom, 1992) & .00 \\
\hline \multicolumn{3}{|l|}{ Absolute fit measures } \\
\hline GFI & $>.90$ (Hair et al., 2010) & .89 \\
\hline RMSEA & $<.08$ (Browne \& Cudeck, 1993) & .05 \\
\hline RMR & $<.05(\mathrm{Wu}, 2009)$ & .04 \\
\hline SRMR & <.05 (Jöreskog \& Sörbom, 1992) & .045 \\
\hline Normed chi-square & $<3$ (Hair et al., 2010) & 1.58 \\
\hline \multicolumn{3}{|c|}{ Incremental fit measures } \\
\hline NFI & $>.90$ (Bentler, 1992) & .85 \\
\hline CFI & $>.90$ (Gerbing \& Anderson, 1992) & .94 \\
\hline \multicolumn{3}{|c|}{ Parsimony fit measurement } \\
\hline AGFI & $>.80$ (MacCallum \& Hong, 1997) & .86 \\
\hline PNFI & $>.50(\mathrm{Wu}, 2009)$ & .73 \\
\hline
\end{tabular}

For H1, The value of the standardized parameter estimates was .58. The standard error was .14, and the $\mathrm{t}$-value was significant ( $\mathrm{p}=4.64^{* * *}$ ). For $\mathrm{H} 2$, The value of the standardized parameter estimates was .19. The standard error was .09, and the t-value was significant ( $p=1.98^{*}$ ). For H3, The value of the standardized parameter estimates was .24. The standard error was .19, and the t-value was significant (p $=2.19^{*}$ ). For H4, The value of the standardized parameter estimates was .51. The standard error was .11, and the $\mathrm{t}$-value was significant $\left(\mathrm{p}=4.02^{* * *}\right)$. For H5, The value of the standardized parameter estimates was .25. The standard error was .17, and the t-value was significant ( $p=2.30^{*}$ ). For H6, The value of the standardized parameter estimates was .28. The standard error was .04, and the t-value was significant (p $\left.=2.82^{* *}\right)$.

Table 3: Standardized parameter estimates for the structural model

\begin{tabular}{llll}
\hline Hypotheses & Estimates & S. E. & t-value \\
\hline H1 & .58 & .14 & $4.64^{* * *}$ \\
H2 & .19 & .09 & $1.98^{*}$ \\
H3 & .24 & .19 & $2.19^{*}$ \\
H4 & .51 & .11 & $4.02^{* * *}$ \\
H5 & .25 & .17 & $2.30^{*}$ \\
H6 & .28 & .04 & $2.82^{* *}$ \\
\hline
\end{tabular}

$* \mathrm{p}<.05 . \quad * * \mathrm{p}<.01 . \quad * * * \mathrm{p}<.001$. 
Figure 2: SEM Model

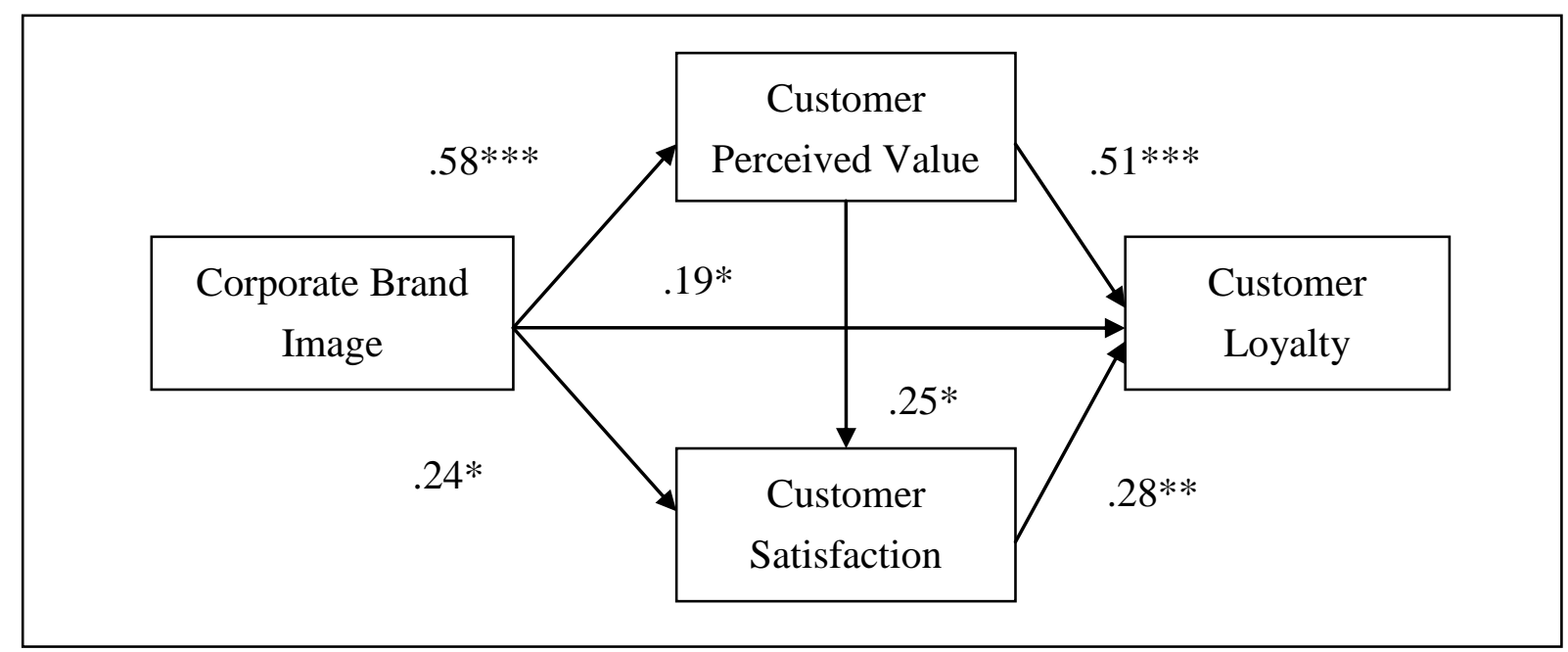

\section{Conclusion}

The results show that the corporate brand image is a direct path, and significantly affects the customer perceived value, therefore, the hypothesis 1 is supported. The result is consistent with the findings of Huang in 2009. The corporate brand image is a direct path, and significantly affects the customer loyalty; therefore, the hypothesis 2 is supported. The result is consistent with the findings of Davies Chun and Roper in 2003. The corporate brand image is a direct path, and significantly affects the customer satisfaction; therefore, the hypothesis 3 is supported. The result is consistent with the findings of Eakuru and Mat in 2008. The customer perceived value is a direct path, and significantly affects the customer loyalty; therefore, the hypothesis 4 is supported. The result is consistent with the findings of Johnson, Andreessen, Lervik, and Cha in 2001. The customer perceived value is a direct path, and significantly affects the customer satisfaction; therefore, the hypothesis 5 is supported. The result is consistent with the findings of Johnson, Andreessen, Lervik, and Cha in 2001. The customer satisfaction is a direct path, and significantly affects the customer loyalty; therefore, the hypothesis 6 is supported. The result is consistent with the findings of Ogba \& Tan in 2009.

Based on the research results, corporate brand image significantly affects customer perceived value, customer satisfaction and loyalty; customer perceived value has strong impact on customer satisfaction and loyalty for the sample; and customer satisfaction significantly affects customer loyalty. Therefore, companies should have a positive brand image to customers, and specifically focus on those factors in order to build a long-term and mutually profitability relationships with customers and create loyalty as competitive advantages in the markets. The study focuses on the industry of shoes in Taiwan, and adopts only a quantitative method. Although the SEM provides a good fit to the hypothesized model, future 
research could employ a different design to examine the causal relationships posited by the theories, and extension the study to discuss mediation or moderation among dimensions.

\section{References}

Aaker, D. A. (1996). Measuring Brand Equity Across Products and Markets. California Management Review, 38(3), 102-120.

ASO. (2013). ASO history. Retrieved from http://www.asogroup.com.tw/index.php

Bagozzi, R. \& Phillips, L. (1982). Representing and testing organizational theories: A holistic construal. Administrative Science Quarterly, 27(3), 459-489.

Bennett, R. \& Rundle-Thiele, S. (2002). A comparison of attitudinal loyalty measurement approaches. Journal of Brand Management, 9(3), 193-207.

Bentler, P. M. (1992). On the Fit of Models to Covariance and Methodology to the Bulletin. Psychological Bulletin, 112(3), 400-404.

Berry, L. L. \& Parasuraman, A. (1991). Marketing Services: Competing through Quality. New York: The Free Press.

Bloemer, J. M. M. \& Odekerken-Schroder, G. (2002). Store satisfaction and store loyalty explained by customer- and store-related factors. Journal of Consumer Satisfaction, Dissatisfaction and Complaining Behavior, 15, 68-80.

Bollen, K. A. (1989). Structural equations with latent variables. Newbury Park, CA: Sage.

Bowen, J. T. \& Shoemaker, S. (2003). Loyalty: A strategic commitment. Cornell Hotel \& Restaurant Administration Quarterly, 44(5/6), 31-46.

Breivik, E. \& Thorbjornsen, H. (2008). Consumer Brand Relationships: An Investigation of Two Alternative Models. Journal of the Academy of Marketing Science, 36, 443-472.

Browne M. W. \& Cudeck, R. (1993). Alternative Ways of Assessing Model Fit, in K. A. Bullen, J. S. Long (ed.), Testing Structural Equation Models. Newbury Park, CA: Sage.

Butz, J. H. E. \& Goodstein, L. (1996). Measuring customer value: gaining the strategic advantage. Organizational Dynamics, 24(3), 63-77.

Chang, T. Z. \& Wildt, A. R. (1994). Price, product information, and purchase intention: An empirical study. Journal of the Academy of Marketing Science, 22, 16-27.

Cronin, J. J., Brady, M. K., Brand, R. R., Hightower, R. Jr. \& Shemwell, D. J. (1997). A cross-sectional test of the effect and conceptualization of service value. The Journal of Services Marketing, 11(6), 375-391.

Davies, G. \& Chun, R. (2002). Gaps between the internal and external perceptions of the corporate brand. Corporate Reputation Review, 5, 144-158.

Davies, G., Chun, R., Da Silva, R. \& Roper, S. (2003). Corporate Reputation and Competitiveness. Routledge, UK: London. 
De-Chernatony, L. (1999). Brand Management through narrowing the gap between brand identity and brand reputation. Journal of Marketing Management, 15, 39-56.

DeMatos, C. A. \& Rossi, C. A. (2008). Word-of-Mouth Communications in Marketing: A Meta-Analytic Review of the Antecedents and Moderators. Journal of the Academy of Marketing Science, 36(4), 578-596.

Dick, A. S. \& Basu, K. (1994). Customer Loyalty: Toward an Integrated conceptual Framework. Journal of Academy of Marketing Science, 22(2), 99-113.

Dimitriades, Z. S. (2006). Customer satisfaction, loyalty and commitment in service organizations: Some evidence from Greece. Management Research News, 29(12), 787-799.

Eakuru, N. \& Mat, N. K. N. (2008). The application of structural equation modeling (SEM) in determining the antecedents of customer loyalty in banks in South Thailand. The Business Review, Cambridge, 10(2), 129-139.

Engel, J. F. \& Blackwell, R. D. (1982). Consumer Behavior. New York: Holt, Rinehart, and Winston.

Fornell, C. \& Larcker, D. F. (1981). Evaluating Structural Equation Models with Unobservable Variables and Measurement Error. Journal of Marketing Research, 18(1), 39-50

Gerbing, D. W. \& Anderson, J. C. (1992). Monte Carlo evaluations of goodness of fit indices for structural equation models. Sociological Methods Research, 21(2), 132-160.

Grahn, G. L. (1969). NBD model of repeat-purchase loyalty: An empirical investigation. Journal of Marketing Research, 6(1), 72-78.

Hair, J. F., Black, W. C., Babin, B. J. \& Anderson, R. E. (2010). Multivariate data analysis. Pearson, NJ: Pearson Education Inc.

Holbrook, M. B. (1994). The nature of customer's value: An axiology of service in consumption experience. In R. T. Rust, \& R. L. Oliver (Eds.), Service quality: New directions in theory and practice (pp. 21-71). Thousand Oaks, CA: Sage Publications.

Huang, H. C. (2009). The Influence of Brand Image, Customer Perceived Value on Brand Loyalty: A Comparative Study on Consumers between Market of Taiwan and Japan. Southern Taiwan University of Science and Technology, Master Thesis.

Hunt, K. H. (1977). Customers Satisfaction/Dissatisfaction--Overview and Future Directions, Conceptualization and Measurement of Customer. Marketing Science Institute, Cambridge, MA.

Ibrahim, H. \& Najjar, F. (2008). Relationship bonding tactics, personality traits, relationship quality and customer loyalty: Behavioral sequence in retail environment. The Icfai University Journal of Services Marketing, 6(4), 1-37.

Ind, N. (1997). The Corporate Brand. Macmillan Press Ltd, Great Britain.

Jacoby, J. (1971). A model of multi-brand loyalty. Journal of Advertising Research, 11(3), 25-31.

Jacoby, J. \& Chestnut, R. W. (1978). Brand Loyalty: Measurement and Management. New York: John Wiley.

Joewono, T. B. \& Kubota, H. (2007). User Satisfaction with Paratransit in Competition with Motorization in Indonesia: Anticipation of Future Implications. Transportation, 33(3), 337-355. 
Johnson, M. D., Andreessen, T. W., Lervik, L. \& Cha, J. (2001). The evolution and future of national customer satisfaction index models. Journal of Economic Psychology, 22, 217-245.

Johnson, M. D., Anderson, E. W. \& Fornell, C. (1995). Rational and adaptive performance expectations in a customer satisfaction framework. Journal of Consumer Research, 21(4), 695-707.

Jones, T. (1996). Why satisfied customer defect. Journal of Management in Engineering, 12(6), 11.

Jones, T. O. \& Sasser, J. W. E. (1995). Why satisfied customers defect. Harvard Business Review, 73(6), 88-99.

Jöreskog, K. G. \& Sörbom, D. (1992). LISREL: A Guide to the Program and Applications. 3rd ed. Chicago: Scientific Software International, Inc.

Keller, K. L. (1993). Conceptualizing, Measuring, and Managing Customer-Based Brand Equity. Journal of Marketing, 57(1), 1-22.

Kline, R. B. (1998). Principles and Practice of Structural Equation Modeling. Guilford Press, New York.

Kotler, P. (2005). According to Kotler: The World's Foremost Authority on Marketing Answers the World's Foremost Authority on Marketing Answers Your Questions. New York: AMACOM.

Lee, E. J. \& Overby, J. W. (2004). Creating value for online shoppers: Implications for satisfaction and loyalty. Journal of Consumer Satisfaction, Dissatisfaction and Complaining Behavior, 17, 54-67.

Lei, P. \& Jolibert, A. (2012). A Three-Model Comparison of the Relationship between Quality, Satisfaction and Loyalty: An Empirical Examination of the Chinese Healthcare System. BMC Health Services Research, 12(1), 436-446.

MacCallum R. C. \& Hong, S. (1997). Power Analysis in Covariance Structure modeling using. Multivariate Behavioral Research, 32(2), 193-210.

Magid, J. M., Anthony, D. \& Dena, S. (2006). Quantifying Brand Image: Empirical Evidence of Trademark Dilution. American Business Law Journal, 43(1), 1-42.

Moliner, M. A., Sanchez, J., Rodriguez, R. M. \& Callarisa, L. (2007). Relationship quality with a travel agency: The influence of the post-purchase perceived value of a tourism package. Tourism and Hospitality Research, 7(3/4), 194-211.

Monroe, K. B. (1990). Pricing: Making Profitable Decisions (2 $2^{\text {nd }}$ ed.). New York: McGraw-Hill.

Morgan, R. P. (2000). A Consumer-Orientated framework of brand equity and loyalty. International Journal of Marketing Research, 42(1), 65-78.

Ogba, I. E. \& Tan, Z. (2009). Exploring the impact of brand image on customer loyalty and commitment in China. Journal of Technology Management in China, 4(2), 132-144.

Oliver, R. L. (1997). Satisfaction: A Behavioral Perspective on the Consumer. New York: McGraw Hill.

Oliver, R. L. \& Swan, J. E. (1989). Equity and Disconfirmation Perception as Influences on Merchant and Product Satisfaction. Journal of Consumer Research, 16(3), 372-383.

Olsen, L. L. \& Johnson, M. D. (2003). Service equity, satisfaction, and loyalty: From transaction-specific to cumulative evaluations. Journal of Service Research, 5(3), 184-195. 
Ostrom, A. \& Iacobucci, D. (1995). Consumer trade-offs and the evaluation of services. Journal of Marketing, 59(1), 17-28.

Park, C. W., Jaworski, B. J. \& Maclnnis, D. J. (1986). Strategic brand concept-image management. Journal of Marketing, 50(4), 135-145

Patterson, P. G. \& Spreng, R. A. (1997). Modeling the relationship between perceived value, satisfaction and repurchase intentions in a business-to-business, services context: An empirical examination. International Journal of Service Industry Management, 8(5), 414-434.

Petrick, J. F. (2002). Development of a multi-dimensional scale for measuring the perceived value of service. Journal of Leaisure Research, 34(2), 119-134.

Porter, S. S. \& Claycomb, C. (1997). The Influence of Brand Recognition on Retail Store Image. Journal of Product \& Brand Management, 6(6), 373-387.

Reichheld, F. F. \& Detrick, C. (2003). Loyalty: A prescription for cutting costs. Marketing Management, 12(5), 24-25.

Reichheld, F. F. \& Teal, T. (1996). The Loyalty Effect: The Hidden Force Behind Growth, Profits, and Lasting Value. Boston, Mass: Harvard Business School Press.

Reichheld, F. F. \& Sasser, W. E. J. (1990). Zero defections: Quality comes to services. Harvard Business Review, 68(5), 105-111.

Roig, J. G. F., Garcia, J. S., Tena, M. A. M. \& Monzonis, J. L. (2006). Customer perceived value in banking services. International Journal of Bank Marketing, 24(5), 266-283.

Romaniuk, J. \& Sharp, B. (2003). Measuring brand perceptions: Testing quantity and quality. Journal of Targeting, Measurement and Analysis for Marketing, 11(3), 218-229.

Roth, M. (1994). Innovations in Defining and Measuring Brand Equity. Advances in Consumer Research, 21, 471-496.

Rust, R. T., Lemon, K. N. \& Zeithaml, V. A. (2004). Return on marketing: Using customer equity to focus marketing strategy. Journal of Marketing, 68(1), 109-127.

Selnes, F. (1993). An examination of the effect of product performance on brand reputation, satisfaction and loyalty. European Journal of Marketing, 27(9), 19-35.

Sirdeshmukh, D., Singh, J. \& Sabol, B. (2002). Consumer trust, value, and loyalty in relational exchanges. Journal of Marketing, 66, 15-37.

Steenkamp J. B. E. M. \& Van Trijp H. C. M. (1991). The use of LISREL in validating marketing constructs. International Journal of Research in Marketing, 8, 283-299

Tse, D. K. \& Wilton, P. C. (1988). Models of consumer satisfaction formation: an extension. Journal of Marketing Research, 25(2), 204-212.

Ulaga, W. \& Chacour, S. (2001). Measuring customer perceived value in business markets: A prerequisite for marketing strategy development and implementation. Industrial Marketing Management, $30(6), 525$. 
Verhoef, P. C. (2003). Understanding the Effect of Customer Relationship Management Efforts on Customer Retention and Customer Share Development. Journal of Marketing, 67(4), 30-45.

Webster, F. E. (1994). Defining the New Marketing Concept. Marketing Management, 2(4), 22-31.

Woodruff, R. B. (1997). Customer value: The next source for competitive advantage. Academy of Marketing Science, 25(2), 139-153.

Wu, C. C. (2011). The impact of hospital brand image on service quality, patient satisfaction and loyalty. African Journal of Business Management, 5(12), 4873-4882.

Wu, M. L. (2009). Structural equation modeling: Amos operation and application. Wu-Nan Book Inc, Taipei, Taiwan.

Zeithaml, V. A. (1988). Consumer perceptions of price, quality, and value: A means-end model and synthesis of evidence. Journal of Marketing, 52(3), 2-22.

Zeithaml, V. A. \& Bitner, M. J. (2000). Services Marketing: Integrating Customer Focus across the Firm. New York: McGraw-Hill Inc. 